\title{
SECONDARY HYPERPARATHYROIDISM AFTER BARIATRIC SURGERY: TREATMENT IS WITH CALCIUM CARBONATE OR CALCIUM CITRATE?
}

\author{
Hiperparatireoidismo secundário após cirurgia bariátrica: tratar com carbonato ou citrato de cálcio?
}

Giorgio Alfredo Pedroso BARETTA, Maria Paula Carlini CAMBI, Arieli Luz RODRIGUES, Silvana Aparecida MENDES

From the Hospital Vita Batel (Vita Batel Hospital), Curitiba, PR, Brazil

\section{Correspondence:}

Maria Paula Carlini Cambi

E-mail: mpcarlini@hotmail.com

Financial source: none

Conflicts of interest: none

Received for publication: 19/02/2015

Accepted for publication: 19/05/2015

DESCRTORES: Hiperparatireoidismo secundário. Cirurgia bariátrica. Deficiências nutricionais
ABSTRACT - Background: Bariatric surgery, especially Roux-en-Y gastric bypass, can cause serious nutritional complications arising from poor absorption of essential nutrients. Secondary hyperparathyroidism is one such complications that leads to increased parathyroid hormone levels due to a decrease in calcium and vitamin $D$, which may compromise bone health. Aim: To compare calcium carbonate and calcium citrate in the treatment of secondary hyperparathyroidism. Method: Patients were selected on the basis of their abnormal biochemical test and treatment was randomly done with citrate or calcium carbonate. Results: After 60 days of supplementation, biochemical tests were repeated, showing improvement in both groups. Conclusion: Supplementation with calcium (citrate or carbonate) and vitamin D is recommended after surgery for prevention of secondary hyperparathyroidism.

\section{INTRODUCTION}

S econdary hyperparathyroidism is a relatively common nutritional disorder among patients undergoing bariatric surgery, in its various techniques. The disease secondary to hyperparathyroidism is characterized by a negative calcium balance, associated or not with vitamin $\mathrm{D}$, which causes an abrupt increase in parathyroid hormone (PTH) levels, with consequent osteopenia or osteoporosis.

The changes in bone metabolism after Roux-en-Y gastric bypass (RYGB) are related to the alterations in intestinal absorption of various nutrients, besides a lower intake of protein foods and hindered absorption of vitamin D.

This study had as objective to analyze the treatment of secondary hyperparathyroidism after RYGB with different calcium salts.

\section{METHODS}

The study was approved by the Research Ethics Committee of Hospital Vita Batel, and all participants signed an informed consent form for inclusion in the study. It was prospective, randomized with 20 patients undergoing RYGB at a private hospital in Curitiba, Paraná, Brazil, in 2013-2014.

Patients with chronic diseases or using medications that interfere with bone metabolism were excluded.

Patients were assessed in regard to the following data: age, gender, body mass index, measurement of serum calcium, alkaline phosphatase, vitamin D and PTH. Patients were selected on basis of their levels of alkaline phosphatase, vitamin $D$ and PTH, which were mainly abnormal. At this time, randomized treatment was suggested 
for the patient with calcium citrate or calcium carbonate to form a group of 10 patients for each treatment. Group 1 received $600 \mathrm{mg}$ calcium citrate, together with 400 IU vitamin D, twice daily for 60 days. Group 2 received $600 \mathrm{mg}$ calcium carbonate combined with 400 IU vitamin D, twice daily. Both groups received the supplements as tablets, and participants were instructed to take them with water and not with meals containing iron.

All patients underwent bone densitometry examinations, and they brought their laboratory test results. Everyone was asked if they exercised and how often.

The data were tabulated in Excel and statistical analysis was performed using tables containing the analysis of the variables: age, body mass index, and serum calcium, alkaline phosphatase, PTH and vitamin D, with the initial (before treatment) and final (after treatment of 60 days) measurements. The Mann-Whitney test was used, and the significance level adopted was $\alpha<0.05$.

\section{RESULTS}

Of the patients selected, nine were men and 11 women. In group 1 treated with calcium carbonate, there were six men and four women, and in group 2 treated with calcium citrate, there were three men and seven women. There was no statistical significance in gender. In group 1 , all patients were sedentary, without any physical activity program. In group 2 , four women worked out twice a week with weights training and treadmill. All others were sedentary.

Bone densitometry of the 20 participants was normal for femur and spine. No statistically significant difference was observed between the groups in relation to bone mineral density of the lumbar spine and femoral neck.

The medium age was 46 years old in both groups (Table 1 ).

TABLE 1 - Statistical analysis between calcium carbonate (citracal) and calcium citrate (compounded) with regard to age

\begin{tabular}{|c|c|c|c|c|c|c|}
\hline \multirow[t]{2}{*}{ Supplement } & $\mathrm{n}$ & \multicolumn{4}{|c|}{ AGE } & $\begin{array}{c}\text { Mann-Whitney } \\
\text { test }\end{array}$ \\
\hline & & mín - max & Mean & \pm & $\mathrm{SD}$ & $p$ \\
\hline Calcium carbonate & 10 & $25-68$ & 49.5 & \pm & 14.4 & 0.16 \\
\hline Calcium citrate & 10 & $25-55$ & 42.7 & \pm & 10.8 & \\
\hline
\end{tabular}

TABLE 2 - Statistical analysis between IMC and calcium carbonate (citracal) and calcium citrate (compounded)

\begin{tabular}{|c|c|c|c|c|c|c|}
\hline Supplement & \multicolumn{1}{c}{$\mathbf{n}$} & \multicolumn{2}{c}{ IMC } & & $\begin{array}{c}\text { Mann-Whitney } \\
\text { test }\end{array}$ \\
\hline & & $\min -\max$ & Mean & \pm & SD & $p$ \\
\hline Calcium carbonate & 10 & $26,0-39,4$ & 33,0 & \pm & 4,3 & 0,97 \\
\hline Calcium citrate & 10 & $29,5-36,0$ & 32,8 & \pm & 2,4 & \\
\hline
\end{tabular}

$\mathrm{n}=$ number of patients; $\min -\mathrm{max}=$ minimum and maximum values; $\mathrm{SD}=$ standard deviation; $p=$ probability value

According to the Tables, no statistically significant differences were found between the two calcium salts, where they were both equally effective in correcting secondary hyperparathyroidism.
TABLE 3-Statistical analysis between calcium carbonate (citracal) and calcium citrate (compounded) regarding to biochemical variables

\begin{tabular}{|c|c|c|c|c|}
\hline \multirow{2}{*}{ Supplement } & \multicolumn{3}{|c|}{ Variable } & \multirow{2}{*}{$\begin{array}{c}\text { Mann- } \\
\text { Whitney test } \\
p\end{array}$} \\
\hline & $\mathrm{n}$ & Min-Max & Mean $\pm S D$ & \\
\hline & \multicolumn{3}{|c|}{ Calcium 1} & \\
\hline Calcium carbonate & 10 & $8,1-8,9$ & $8.7 \pm 0.2$ & 0.97 \\
\hline \multirow[t]{2}{*}{ Calcium citrate } & 10 & $8,2-9,0$ & $8.6 \pm 0.3$ & \\
\hline & \multicolumn{3}{|c|}{ Alkaline phosphatase 1} & \\
\hline Calcium carbonate & 10 & $119,4-180$ & $135.8 \pm 18.6$ & 0.91 \\
\hline \multirow[t]{2}{*}{ Calcium citrate } & 10 & $100,0-163,0$ & $132.8 \pm 23.2$ & \\
\hline & \multicolumn{3}{|c|}{ PTH 1} & \\
\hline Calcium carbonate & 10 & $68,7-92,0$ & $82.7 \pm 8.8$ & 0.80 \\
\hline \multirow[t]{2}{*}{ Calcium citrate } & 10 & $67,5-95,0$ & $84.0 \pm 8.9$ & \\
\hline & \multicolumn{3}{|c|}{ Vitamin D 1} & \\
\hline Calcium carbonate & 10 & $17,0-28,9$ & $-22.8 \pm 4.4$ & 0.85 \\
\hline \multirow[t]{2}{*}{ Calcium citrate } & 10 & $16,0-29,0$ & $22.2 \pm 3.9$ & \\
\hline & \multicolumn{3}{|c|}{ Calcium 2} & \\
\hline Calcium carbonate & 10 & $8,1-8,9$ & $8.7 \pm 0.3$ & 0.48 \\
\hline \multirow[t]{2}{*}{ Calcium citrate } & 10 & $8,1-10,0$ & $8.6 \pm 0.6$ & \\
\hline & \multicolumn{3}{|c|}{ Alkaline phosphatase 2} & \\
\hline Calcium carbonate & 10 & $82,3-120,0$ & $98.3 \pm 12.5$ & 0.58 \\
\hline \multirow{2}{*}{ Calcium citrate } & 10 & $87,5-120,0$ & $101.0 \pm 10.4$ & \\
\hline & \multicolumn{3}{|c|}{ PTH 2} & \\
\hline Calcium carbonate & 10 & $29,0-65,0$ & $47.9 \pm 9.7$ & 0.12 \\
\hline \multirow[t]{2}{*}{ Calcium citrate } & 10 & $42,0-64,0$ & $54.2 \pm 7.2$ & \\
\hline & \multicolumn{3}{|c|}{ Vitamin D 2} & \\
\hline Calcium carbonate & 10 & $25,0-35,0$ & $30.6 \pm 3.3$ & 0.85 \\
\hline Calcium citrate & 10 & $25,0-36,0$ & $30.9 \pm 3.6$ & \\
\hline
\end{tabular}

$\mathrm{n}=$ number of patients; $\min$ - max - minimum and maximum values; $\mathrm{SD}=$ standard deviation; $p=$ probability value

\section{DISCUSSION}

RYGB causes a significant reduction in the absorption of nutrients such as calcium and vitamin $\mathrm{D}^{1,2}$. This nutritional loss is easily detected through regular metabolic monitoring. The mineral density is low independent the lost weight after RYGB for low calcium absorption cause low vitamin $D$ activation dependent the calcium ${ }^{3}$.

This study revealed the presence of secondary hyperparathyroidism after RYGB. All patients subjected to surgical treatment for obesity must use calcium and vitamin D supplements to prevent possible deficiencies. The main question has been what kind of supplements would be most effective in protecting the body from deficiencies in calcium and vitamin $D$ and consequent complications.

Calcium is mainly absorbed in the small intestine by active transport and passive diffusion. Approximately onethird of ingested calcium is absorbed, although it may vary depending on the form of the salt, dietary factors and the state of the small intestine. After absorption, calcium is eventually incorporated into bones and teeth with $99 \%$ of the amount of calcium present in the skeletal tissue of the body. The remaining is present in both the intra- and extracellular fluid. Approximately $47 \%$ of the total blood content of calcium is in the physiologically active ionized form with approximately $6 \%$ in complex with citrate, phosphate or other anions and the rest bound to proteins, primarily albumin. The absorption of calcium from calcium citrate is much higher than that of calcium carbonate ${ }^{4,5}$. In the present study, was found an improvement only in PTH with calcium supplementation, with both calcium carbonate and calcium citrate having positive effects.

Calcium can be bound to albumin (40\%) and other anions (citrate and phosphate - 10\%) and can be in the ionized form $(50 \%)^{6}$. It functions in the permeability of cell membranes, muscle contraction and relaxation, nerve excitability, activation 
of enzymes and blood clotting. Its regulation involves some hormones such as vitamin D, PTH and calcitonin. Absorption occurs throughout the small intestine and jejunum and is influenced by several factors: $\mathrm{pH}$, food intake (which may be a determinant factor for patients with RYGB, who have drastically lower protein intake), fat intake (also decreased among operated patients), amino acids, and intestinal motility? That effervescent potassium calcium citrate was superior to citracal in conferring bioavailable calcium and suppressing parathyreoid hormone secretion ${ }^{8}$.

PTH is a hormone secreted by the parathyroid glands, which is controlled by calcium concentration. It has biological effects in three target organs, bones, kidneys and intestinal mucosa ${ }^{9}$.

In extracellular metabolism, ionized calcium is metabolically better available and reflects the concentration of calcium. Both acidosis and alkalosis alter the binding capacity and amount of calcium. It acts physiologically with PTH and $1.25(\mathrm{OH})_{2} \mathrm{D}_{3}{ }^{10,11}$.

A low concentration of circulating calcium leads to increased PTH and a reduction in bone mass, particularly a depletion of calcium and phosphorus, in attempt to increase blood calcium. At the same time, the kidneys increase the excretion of phosphorus and calcitriol and reduce calcium excretion ${ }^{12,13}$.

This whole mechanism causes secondary hyperparathyroidism which should be treated with calcium and vitamin $\mathrm{D}^{13}$. In the present study, this change in calcium excretion was not enough to cause osteopenia, osteomalacia or osteoporosis in the 20 participants. All received supplementation on time with either calcium carbonate or calcium citrate, reversing this complication after RYGB.

There were some limitations in this study. The participants underwent bone densitometry at various laboratories ${ }^{14}$. Protein intake was not fully investigated, but in a $24 \mathrm{~h}$ dietary record examined during nutritional consultation, it was possible to see the drastic decrease in protein intake as a whole and in many patients, particularly in the intake of protein rich in calcium, such as milk due to unwanted lactose intolerance, which can occur after RYGB.

It is interesting to note the importance of time of use of the calcium supplement, where calcium citrate or calcium carbonate, combined with vitamin $\mathrm{D}$, for 60 days was sufficient to correct PTH values. What needs to be emphasized is that patients should use supplementation routinely and have regular blood tests to avoid hypervitaminosis and cardiac complications due to excess calcium.

Supplementation is recommended in the immediate postoperative period to prevent the progressive loss of bone mass ${ }^{15,16}$. Many patients do not adhere to regular supplement use. They ignore the fact of intestinal malabsorption, where many important absorptive sites are lost, and furthermore hypochlorhydria can also compromise the absorption of calcium ${ }^{17}$. Idealy may be to start with $1000 \mathrm{mg}$ calcium malat citrate and calcium carbonate, with $400 U$ I vitamin $D_{3}$ together after the surgery for prevent secondary hyperparathyroidism.

Further studies are needed to compare citrate and carbonate salts for the treatment of secondary hyperparathyroidism after RYGB, including detailed monitoring of protein intake and urinary and fecal excretion.
CONCLUSION

Both treatments with calcium malat citrate and calcium carbonate associated with vitamin $\mathrm{D}_{3}$ are efficient to correct the secondary hyperparathyroidism after the bariatric surgery.

\section{REFERENCES}

1. Buchwald $H$, Avidor $Y$, Braunwald $E$, Jensen $M D$, PoriesW, Fahrbach K, Schoelles K (2004) Bariatric surgery: a systematic review and meta-analysis. JAMA 292:1724-1737.

2. Bloomberg RD, Fleishman A, Nalle JE, Herron DM, Kini S (2005) Nutritional deficiencies following bariatric surgery: what have we learned? Obes Surg 15:145-154

3. Sanchez-Hernandez J, Ybarra J, Gich I, De Leiva A, Rius X, RodriguezEspinosa J, Perez A (2005) Effects of bariatric surgery on vitamin D status and secondary hyperparathyroidism: a prospective study. Obes Surg 15:1389-1395

4. Harvey JA et al. Superior calcium absorption from calcium citrate than calcium carbonate using external forearm counting. J Am Coll Nutr 1990 dec; 9 (6): 583- 7.

5. Harvey JA, Zobitz MM, PAK CY. Dose dependency of calcium absorption a comparison of calcium carbonate and calcium citrate. J Bone Miner Res, 1988, jun; 3 (3): 253 - 8.

6. Fleischer J, Stein EM, Bessler M, Della Badia M, Restuccia N, OliveroRivera L, McMahon DJ, Silverberg SJ (2008) The decline in hip bone density after gastric bypass surgery is associated with extent of weight loss. J Clin Endocrinol Metab 93:3735-3740

7. Valderas JP, Velasco S, Solari S, Liberona Y, Viviani P, Maiz A, Escalona A, Gonzalez G (2009) Increase of bone resorption and the parathyroid hormone in postmenopausal women in the long-term after Rouxen-Y gastric bypass. Obes Surg 19:1132-1138

8. Sakhaee K, PAK C. Superior Calcium bioavailability of effervescent potassium calcium citrate over tablet formulation of calcium citrate ofter Roux-en-Y gastric bypass. Surg Obes Relat Dis. 2013. Sep-Oct; 9 (5) $743-8$

9. DiGiorgi M, Daud A, InabnetWB, Schrope B, Urban-Skuro M, Restuccia N, Bessler M (2008) Markers of bone and calcium metabolism following gastric bypass and laparoscopic adjustable gastric banding. Obes Surg 18:1144-1148

10. Lehto-Axtelius D, Stenstrom M, Johnell O (1998) Osteopenia after gastrectomy, fundectomy or antrectomy: an experimental study in the rat. Regul Pept 78:41-50

11. Folli F, Sabowitz BN, Schwesinger W, Fanti P, Guardado-Mendoza R, MuscogiuriG (2012) Bariatric surgery and bone disease: from clinical perspective to molecular insights. Int J Obes (Lond) 36:1373-1379

12. Kleinman NL, Melkonian A, St B, Rohrbacker N, Lynch WD, Gardner $\mathrm{HH}$ (2009) The impact of morbid obesity and bariatric surgery on comorbid conditions: a comprehensive examination of comorbidities in an employed population. J Occup Environ Med 51:170-179

13. Vilarrasa N, San Jose P, Garcia I, Gomez-Vaquero C, Miras PM, de Gordejuela AG, Masdevall C, Pujol J, Soler J, Gomez JM (2011) Evaluation of bone mineral density loss in morbidly obese women after gastric bypass: 3-year follow-up. Obes Surg 21:465-472

14. Sinha N, Shieh A and Bockman RS. Increased PTH and 1,25 (OH)2 D3 levels associated with increased markers of bone turnover following bariatric surgery. Obesity Dec 2011; 19 (12): 2388 - 2393.

15. El-Kadre LJ, Rocha PR, de Almeida Tinoco AC, Tinoco RC (2004). Calcium metabolism in pre - and postmenopausal morbidly obese women at baseline and after laparoscopic Roux-en-Y gastric bypass. Obes Surg 14: 1062 - 1066.

16. Santos MTA, Souza FIS, Fonseca FLA, Castro ML, Sarno OS. Alterações de parâmetros relacionados ao metabolismo ósseo em mulheres submetidas à derivação gástrica em $Y$ de Roux. Arq Bras Endocr Metab. V. 56, n.6, SP, ago 2012.

17. KRAUSE M, et al. Calcium gluconate supplementation is effective to balance calcium homeostasis in patients with gastrectomy. Osteoporos Int. 2014, nov 13 